\title{
Custodia compartida y régimen de visitas para un animal de compañía. Comentario sobre la Sentencia no 465/14 de la Audiencia Provincial de Barcelona, Sección $\mathbf{1 2}^{1}$.
}

\author{
Magda Oranich ${ }^{2}$
}

\section{RESUMEN}

En un procedimiento de divorcio, la Audiencia Provincial de Barcelona se pronuncia ante la solicitud del demandante de que le sea concedida la custodia compartida de la perra que convivía con la pareja, o bien que se determine un régimen de visitas a su favor, con la finalidad de poder seguir manteniendo la relación con el animal. El Tribunal reconoce expresamente que los animales son seres vivos, pero que en su calidad de bienes muebles pueden ser reclamados en propiedad y objeto de uso compartido, según el régimen de comunidad de bienes, pretensión que deberá ser deducida en el correspondiente juicio declarativo y no en el presente proceso de carácter matrimonial. La Sentencia comentada recoge el voto particular de uno de los magistrados, que considera que la Audiencia sí debería haber resuelto también esta cuestión.

\section{INTRODUCCIÓN.-}

Se trata de una sentencia que dicta el Tribunal de apelación en un caso de divorcio contencioso. En este caso, como en tantos otros, se realizan peticiones en relación al animal doméstico que tenía la familia, en este supuesto una perra llamada Estel.

La sentencia del Juzgado de Primera Instancia de Mataró (Juzgado no1 de Violencia sobre la mujer) dicta concretamente: "7. No ha lugar a acordar nada en relación a la tenencia de la perra Estel".

El marido presenta recurso de apelación (por este motivo y por otros muchos que no mencionaremos por no tener que ver con la cuestión que nos ocupa), en el que solicita la concesión de una custodia compartida de la perra Estel por meses alternos, o bien

\footnotetext{
${ }^{1}$ http://www.derechoanimal.info/bbdd/Documentos/1443.pdf

2 Abogada y periodista. Especialista en Derecho de Familia. Presidenta de la Comissió de Drets dels Animals del Il.lustre Col.legi d’ Advocats de Barcelona, (Comisión de Derechos de los Animales del Ilustre Colegio de Abogados de Barcelona).
} 
que se determine un régimen de visitas a su favor, con la finalidad de poder seguir manteniendo la relación con el animal.

El Tribunal de Instancia no da lugar al recurso, pero sí entra a valorar la cuestión relativa a la tenencia del animal de compañía, respecto a lo cual realiza unos interesantes e innovadores razonamientos jurídicos, que se recogen a continuación.

\section{PRONUNCIAMIENTO DE LA AUDIENCIA PROVINCIAL.-}

En su sentencia la Audiencia Provincial reconoce la importancia de la cuestión planteada, a la que niega un carácter "baladi": "pues es frecuente en muchos hogares españoles la tenencia en el seno de la convivencia familiar de determinados animales domésticos (...) creándose entre la mascota y todos los miembros de la familia lazos afectivos, dedicándose a su cuidado, y asumiendo sus necesidades de alimento, higiene y tratamiento veterinario". Derivado de lo anterior, la Audiencia reconoce el daño que para uno de los consortes supondría la privación de la compañía del animal, en cuanto dicha privación produce "sentimientos de tristeza, desasosiego, ansiedad y añoranza". Ante la solicitud del recurrente de que se conceda la custodia compartida del animal o bien que se determine un régimen de visitas, el Tribunal descarta la aplicación de los artículos 233 y siguientes del Código Civil de Cataluña ${ }^{3}$, que "no regulan entre las medidas provisionales ni en las definitivas de la separación, divorcio o nulidad del matrimonio la cuestión de los animales domésticos", así como la aplicación analógica de lo preceptuado en cuanto al régimen de visitas de los progenitores no custodios respecto a los hijos menores de edad, posibilidad que califica de "improcedente".

A partir de lo anterior, la sentencia analizada reconoce expresamente que los animales son seres vivos, pero que en su calidad de bienes muebles pueden ser reclamados en propiedad y objeto de uso compartido, según el régimen de comunidad de bienes:

"Los animales domésticos no se encuentran en la categoría de los enseres personales, ni en la naturaleza propia del ajuar doméstico, pues su inclusión en una de esas categorías supondría una interpretación forzada de los preceptos sustantivos que regulan la materia.

Las mascotas domésticas son pues seres vivos, que en concepto de bienes muebles se encuentran en el domicilio familiar, susceptibles de ser reclamados en propiedad, y en el supuesto de titularidad dominical conjunta, proceder al ejercicio de acciones en proceso declarativo, tendentes a obtener la división

\footnotetext{
${ }^{3}$ http://www.boe.es/buscar/act.php?id=BOE-A-2010-13312
} 
del bien común, o el uso compartido, sin detrimento de la utilización por el otro partícipe en la propiedad, que constituye derecho inherente al régimen de la comunidad de bienes.

La alegación de la demandante de no conceder que el demandado tenga en su compañía a la mascota Estel, por entender que ostenta la titularidad administrativa de la misma, se desvanece por la aplicación del artículo 232-3.2 del Código Civil de Cataluña, que determina que si los bienes se adquieren a título oneroso, en el régimen matrimonial de separación de bienes, durante el matrimonio y son de valor ordinario destinados al uso familiar, cual aquí sucede con la mascota controvertida, se presume que pertenece a ambos cónyuges por mitad indivisa, sin que prevalezca contra tal presunción la mera prueba de la titularidad forma ${ }^{4}$.

En base a las consideraciones jurisdiccionales dichas, es factible deducir la pretensión del recurrente sobre la mascota familiar, en proceso distinto al presente de carácter matrimonial, y en concreto en juicio declarativo, tal como hemos expresado".

\section{VOTO PARTICULAR.-}

A pesar de dichos razonamientos, uno de los tres magistrados del Tribunal, Joaquín Bayo Delgado, va más lejos en la consideración legal que deben tener los animales y opina de manera clara que Sí debía entrar el Tribunal a resolver sobre la tenencia y cuidado de Estel.

Concretamente, en su voto particular este magistrado expone lo siguiente:

"Comparto el criterio de no asimilar ese pronunciamiento a un régimen de relación paterno-filial pero no estoy de acuerdo en asimilar a un animal de compañía (según el artículo 3.b del Texto refundido de la Ley catalana de protección de los animales ${ }^{5}\lfloor$ a los bienes muebles distintos al ajuar doméstico o a los enseres personales de los miembros de la familia. Los lazos afectivos que la propia sentencia reconoce hacen que los animales domésticos o de compañía formen parte del hogar familiar y como tales más asimilables a los objetos vinculados al domicilio que a los meros bienes muebles que pueden ser

\footnotetext{
${ }^{4}$ El Juzgado de Primera Instancia no 40 de Madrid, en Sentencia de 12-03-2013, denegó la solicitud de custodia compartida sobre un perro precisamente porque una de las partes había acreditado que el animal era de su propiedad, al haber sido un regalo de un familiar y estar el microchipo y otra documentación a su nombre. http://www.derechoanimal.info/images/pdf/ASR-Sta-Custodia-compartida-perro-3.pdf

${ }^{5}$ http://www.derechoanimal.info/bbdd/Documentos/458.pdf
} 
objeto de un proceso declarativo al margen del proceso de familia. Así pues, esa asimilación no lleva a poder aplicar el artículo 233-4.2 ccCat interpretado según la realidad social y a reqular judicialmente la tenencia de los animales domésticos con criterios adecuados a su condición de seres vivos, vinculados a los miembros de la familia con lazos afectivos que deben ser protegidos. El artículo 233-1.g) CCCat, en sede de medidas provisionales, contempla la regulación judicial de la tenencia de bienes comunes, lo cual también lleva a interpretar el artículo 233-4.2 CCCat en esa línea, para evitar el contrasentido de que se pueda regular una materia provisionalmente pero luego no quepa adoptar una medida definitiva sobre ella, en un tema claramente incluido en el concepto de hogar, que no es el caso de otros bienes comunes (respecto de los que solo cabe imaginar la medida provisional cuando se ejercita la acción de división).

Así pues, la sentencia de la que sólo parcialmente disiento ha debido regular la tenencia y cuidado de la mascota familiar."

\section{CONCLUSIÓN.-}

La presente Sentencia ya contiene en sí misma un trato avanzado hacia el animal que convive con una familia. No podemos olvidar que aunque el Código Civil catalán declara que los animales no son cosas (artículo $511.3 \mathrm{CCCat}^{6}$ ), en realidad el régimen jurídico que se les aplica sigue siendo el de aquéllas. En el mejor de los casos, como en la sentencia que comentamos, se reconoce expresamente y se razona que son seres vivos.

Pero desde mi punto de vista el punto más innovador de la sentencia es el contenido en el razonamiento del magistrado Joaquín Bayo, en su afirmación clara y contundente de no estar de acuerdo en asimilar un animal a bienes muebles distintos del ajuar doméstico a los enseres personales de los miembros de la familia. El magistrado se refiere a la realidad social en relación al cariño para con los animales y su vínculo con las personas. La palabra vínculo, aquí, es clave.

Éste es, a mi entender, el camino a seguir y por consiguiente creo que debería modificarse la legislación actual, en el sentido de prever de manera específica un apartado relativo a los animales domésticos. En cualquier caso, la sentencia comentada, y muy especialmente el voto particular del magistrado Joaquín Bayo,

\footnotetext{
${ }^{6}$ http://www.derechoanimal.info/bbdd/Documentos/604.doc
} 
dA derecho ANIMAL la web center de los animales con derecho

constituyen sin duda importantes pasos hacia adelante, en cuanto contienen razonamientos muy innovadores respecto a los animales de compañía. 